\title{
Acute Coronary Syndromes
}

${ }^{1}$ Department of Cardiology, University Hospital Bern, Switzerland.

\section{Management and Secondary Prevention}

\author{
Peter Wenaweser, Stephan Windecker ${ }^{1}$
}

\begin{abstract}
Acute coronary syndromes represent a broad spectrum of ischemic myocardial events including unstable angina, non-ST elevation myocardial infarction and acute ST elevation myocardial infarction, which are associated with high morbidity and mortality. They constitute the most frequent cause of hospital admission related to cardiac disease. Early diagnosis and risk stratification are essential for initiation of optimal medical and invasive manage-
\end{abstract}

ment. Therapeutic measures comprise aggressive antiplatelet, antithrombotic, and anti-ischemic agents. In addition, patients with high-risk features, notably positive troponin, ST segment changes and diabetes, benefit from an early invasive as compared to a conservative strategy. Importantly, lifestyle interventions, modification of the risk factor profile, and long-term medical treatment are of pivotal importance in reducing the long-term risk of recurrence.

\section{Key Words:}

Acute coronary syndrome $\cdot$ Risk stratification and treatment $\cdot$ Prevention

Herz 2008;33:25-37

DOI $10.1007 /$ s00059-008-3078-4

\section{Akutes Koronarsyndrom. Management und Sekundärprävention}

\section{Zusammenfassung}

Das akute Koronarsyndrom umfasst ein breites Spektrum myokardialer Ischämien, die von der instabilen Angina pectoris über den Nicht-ST-Hebungsinfarkt bis zum akuten ST-Strecken-Hebungsinfarkt reichen. Akute Koronarsyndrome stellen die häufigste Ursache für kardial bedingte Hospitalisationen dar. Die rasche Diagnose sowie Risikostratifizierung sind für die Einleitung der optimalen medikamentösen und invasiven Behandlung von großer Bedeutung. Therapeutische

\section{Introduction}

Acute coronary syndromes (ACS) represent a wide spectrum of ischemic myocardial events ranging from unstable angina (UA) over myocardial infarction (MI) to sudden death. The common pathophysiological substrate is coronary thrombosis following rupture or erosion of an atherosclerotic plaque causing ischemia in the corresponding myocardial area [1]. The extent of intracoronary thrombosis and distal embolization determines the clinical presentation ranging from UA without myocardial necrosis over non-ST segment elevation (NSTEMI) to ST segment elevation myocardial infarction (STEMI; Table 1). Diagnosis and risk stratification of ACS are based on history, electrocardiographic changes, and cardiac biomarkers [2]. The present overview deals with the management of patients with NSTE-ACS (UA and NSTEMI).

\section{Diagnosis and Risk Stratification}

With over 2.5 million annual hospitalizations worldwide, ACS account for the most common cause of hos-
Maßnahmen umfassen potente antiischämische und antithrombotische Substanzen sowie eine rasche und wirkungsvolle Inhibition der Blutplättchenaggregation. Darüber hinaus profitieren Patienten mit erhöhtem Risiko, wie beispielsweise troponinpositive Patienten, Patienten mit ST-Strecken-Senkungen sowie Diabetiker, von einer frühen invasiven Abklärung. Modifikationen des Lebensstils sowie von Risikofaktoren komplementieren die langfristige medikamentöse Therapie, um das Rezidivrisiko zu minimieren.

pital admission for cardiac disorders, and $50 \%$ of coronary care unit admissions. The number of hospitalizations for NSTE-ACS continues to rise, whereas the number of STE-ACS stabilizes or even declines.

\section{Clinical Presentation}

Patients with NSTE-ACS usually present with one of four clinical patterns:

(1) rest angina of prolonged duration (>20 min),

(2) new-onset (de novo) severe angina of at least CCS (Canadian Cardiovascular Society) class III,

(3) accelerating angina of previously diagnosed stable angina that has become more frequent, longer in duration, or lower in threshold,

(4) post-MI angina.

Patients with NSTE-ACS usually experience angina at rest $(80 \%)$, whereas de novo or accelerated angina is observed in $20 \%$. The duration and intensity of angina are graded according to the CCS classification (CCS IIV). The initial patient evaluation aims at determining the likelihood that signs and symptoms are related to

\section{Schlüsselwörter:}

Akutes Koronarsyndrom . Risikostratifizierung und Behandlung · Prävention 
Table 1. Acute coronary syndromes. GP: glycoprotein; LBBB: left bundle branch block; NSTEMI: non-ST elevation myocardial infarction; $\mathrm{PCl}$ : percutaneous coronary intervention; STEMI: ST elevation myocardial infarction; UA: unstable angina.

Tabelle 1. Akutes Koronarsyndrom. GP: Glykoprotein; LBBB: Linksschenkelblock; NSTEMI: Nicht-ST-Strecken-Hebungsinfarkt; $\mathrm{PCl}$ : perkutane Koronarintervention; STEMI: ST-StreckenHebungsinfarkt: UA: instabile Angina pectoris.

\begin{tabular}{|c|c|c|c|c|c|c|}
\hline Type & Symptoms & ECG & $\begin{array}{l}\text { Myocardial } \\
\text { necrosis }\end{array}$ & Coronary lesion & Acute treatment & Prognosis \\
\hline UA & $\begin{array}{l}\text { Recurrent chest pain } \\
<20 \text { min }\end{array}$ & $\begin{array}{l}\text { No ST elevation } \\
\text { ST depression } \\
\text { T wave inversion }\end{array}$ & None & $\begin{array}{l}\text { Severe stenosis } \\
\text { Small thrombus }\end{array}$ & $\begin{array}{l}\text { Aspirin } \\
\text { Clopidogrel } \\
\text { Thrombin inhibitors }\end{array}$ & $\begin{array}{l}\text { Reinfarction } \\
\text { Recurrent } \\
\text { ischemia }\end{array}$ \\
\hline NSTEMI & $\begin{array}{l}\text { Recurrent chest } \\
\text { pain }<20 \text { min }\end{array}$ & $\begin{array}{l}\text { No ST elevation } \\
\text { ST depression } \\
\text { T wave inversion }\end{array}$ & Minor & $\begin{array}{l}\text { Partial thrombotic } \\
\text { occlusion with or without } \\
\text { distal embolization or } \\
\text { severe stenosis }\end{array}$ & $\begin{array}{l}\text { Aspirin } \\
\text { Clopidogrel } \\
\text { Thrombin inhibitors } \\
\text { GP IIb/IIIa antagonists } \\
\text { Early revascularization }\end{array}$ & $\begin{array}{l}\text { Reinfarction } \\
\text { Recurrent } \\
\text { ischemia }\end{array}$ \\
\hline STEMI & $\begin{array}{l}\text { Severe chest pain } \\
>20 \text { min duration }\end{array}$ & $\begin{array}{l}\text { ST elevation } \\
\text { LBBB } \\
\text { New Q wave }\end{array}$ & Large & $\begin{array}{l}\text { Total and persistent } \\
\text { thrombotic occlusion }\end{array}$ & $\begin{array}{l}\text { Immediate reperfusion } \\
\text { Primary PCI } \\
\text { Thrombolysis }\end{array}$ & $\begin{array}{l}\text { Reinfarction } \\
\text { Heart failure } \\
\text { Arrhythmias }\end{array}$ \\
\hline
\end{tabular}

obstructive coronary artery disease. The most important predictors of ischemia due to coronary artery disease are summarized in Table 2.

\section{Physical Examination}

Physical examination in a patient with suspected ACS is frequently normal. A high risk of adverse clinical outcome is present in patients with hemodynamic instability, the presence of pulmonary edema, or an S3 heart sound, and a new or increasing mitral regurgitation murmur. Physical examination is directed to the exclusion of extracardiac chest pain causes such as pericarditis, pneumothorax and aortic dissection, and search for signs of hemodynamic instability and left ventricular dysfunction.

\section{Electrocardiography}

Electrocardiography allows for classification into STEMI and NSTEMI and should be obtained within $10 \mathrm{~min}$ upon arrival in the emergency room (Figure 1). ST segment depression with or without $\mathrm{T}$ wave changes are the most characteristic ECG findings in NSTE-ACS patients [3]. ST segment depression as little as $0.05 \mathrm{mV}$ is a predictor of adverse outcome with increasing severity of ST segment depression translating into progressively increased risk. Widespread ST segment depression in more than six leads is highly specific for acute $\mathrm{MI}$ as is intermittent ST segment elevation. Deep and symmetric $\mathrm{T}$ wave inversion in leads $\mathrm{V}_{2}-\mathrm{V}_{4}$ usually suggests ischemia caused by a proximal lesion of the left anterior descending artery. ST segment depression in leads $\mathrm{V}_{1}-\mathrm{V}_{3}$ may reveal a true posterior infarction, which should be approached like a STEMI. Of note, a normal ECG does not exclude the possibility of an ACS, since $1-6 \%$ of such patients are subsequently found to have acute MI as evidenced by elevated biomarkers.

Nonspecific ST segment and T wave changes, defined as ST segment depression of $<0.05 \mathrm{mV}$ or T wave inversion of $<0.2 \mathrm{mV}$ are less diagnostic for acute ischemia. In addition, alternative causes for ST segment and $\mathrm{T}$ wave abnormalities ought to be considered such as left ventricular hypertrophy, pericarditis, myocarditis, early repolarization, electrolyte imbalances, metabolic disorders, digitalis effect, tricyclic antidepressants, phenothiazines, and central nervous system pathologies.

A resting twelve-lead ECG does not reflect the dynamic nature of coronary thrombosis in patients with ACS. Thus, up to two thirds of ischemic episodes in ACS patients remain clinically silent without associated chest discomfort. Continuous twelve-lead ECG monitoring studies have shown that $15-30 \%$ of ACS patients have transient episodes of ST segment depression, which are associated with adverse outcome. Accordingly, continuous ST segment monitoring adds diagnostic and prognostic information in ACS patients.

\section{Biochemical Markers of Myocardial Injury}

$\mathrm{MI}$ is diagnosed when blood levels of sensitive and specific markers (troponins T and I, CK-MB [myocardial type of creatine kinase]) are increased in the clinical setting of acute ischemia. Elevated cardiac biological markers without signs of acute ischemia should prompt the search for alternative causes of cardiac damage such as trauma, pulmonary embolism, hypertensive crisis, myocarditis, etc., since these markers indicate myocardial damage without shedding light on its mechanism. Importantly, no current marker is detectable immediately upon onset of MI and therefore requires repeated measurements during the first 6-12 h after admission (Figure 2).

Troponin has become the preferred biomarker for assessment of myocardial damage due to its high cardiac specificity and sensitivity. Troponins $\mathrm{T}$ and $\mathrm{I}$ are detectable in blood within 4-12 h after the onset of MI, and peak values are observed at $12-48 \mathrm{~h}$. Since troponin levels may stay elevated for 7-10 days after myocardial necrosis, the attribution of cardiac troponin levels to other than recent clinical events proves difficult. A 
positive troponin test increases the risk of death two- to ninefold, and the risk of death or MI two- to fourfold compared with troponin-negative patients [4]. Troponin-positive patients derive the greatest benefit from an early invasive strategy with revascularization (40\% reduction in recurrent cardiac events) and use of GP IIb/ IIIa antagonists (50\% reduction in recurrent cardiac events). Several other biomarkers have been associated with NSTE-ACS including high-sensitive CRP and natriuretic peptides such as B-type natriuretic peptide (BNP) or its prohormone fragment (NT-proBNP). As markers of inflammation and neurohumoral activation, they provide prognostic information and may help to differentiate patients with chest pain and dyspnea.

\section{Risk Stratification}

Risk stratification represents an essential tool to perform triage, to select the site of care, to define best medical treatment, and to decide upon an invasive strategy. In clinical practice, a risk stratification score has to be simple and easily assessable. The GRACE risk score [5] implements relevant clinical, electrocardiographic and laboratory variables and is recommended as the preferred classification besides the TIMI risk score [6], which is simpler to calculate but provides less predictive power.

\section{Treatment of NSTE-ACS Patients}

The primary goal of the initial treatment in patients with NSTE-ACS is the restoration of coronary blood flow and resolution of ischemia. The four pillars of acute treatment for patients with NSTE-ACS consist of:

(1) antiplatelet agents,

(2) anticoagulants,

(3) anti-ischemic therapy,

(4) coronary revascularization

and are summarized in Figure 3.

\section{Antiplatelet Agents}

Aspirin. Aspirin inhibits platelet cyclooxygenase-1 (COX-1) by irreversible acetylation preventing the formation of thromboxane $\mathrm{A}_{2}$, and thus reducing platelet aggregation and the likelihood of arterial thrombi formation. Aspirin reduces the relative risk of death by $15 \%$, and of nonfatal MI by $30 \%$ both in acute ischemic syndromes and during secondary prevention (Figure 4) [7-9]. The benefit of aspirin is present over a wide range of doses, whereas the risk of bleeding appears to be dose-dependent. Thus, in the CURE trial, aspirin was given in conjunction with clopidogrel in doses ranging from 75 to $325 \mathrm{mg}$, and the risk of bleeding was found to be lowest with aspirin doses up to $100 \mathrm{mg}$ [10]. Accord-
Table 2. Clinical symptoms of unstable angina/non-ST elevation myocardial infarction suggestive of obstructive coronary artery disease. ACS: acute coronary syndrome; $\mathrm{MI}$ : myocardial infarction.

Tabelle 2. Symptome bei instabiler Angina pectoris/Nicht-ST-Hebungsinfarkt, die auf eine flussbehindernde koronare Herzkrankheit hindeuten. ACS: akutes Koronarsyndrom; MI: Myokardinfarkt.

(1) Characteristics of symptoms

- Chest or left arm pain, reproducing prior documented angina, relieved promptly by nitroglycerin

- Atypical chest pain does not exclude the possibility of ACS!

(2) Demographics and prior history

- Prior history of MI

(3) Male sex

- Male patients are more likely to have obstructive coronary artery disease

(4) Age $>65$ years

- Increased risk of both underlying coronary artery disease and multivessel disease

(5) Number of atherosclerotic risk factors present

- Diabetes mellitus

- Extracardiac manifestation of atherosclerotic disease

\begin{tabular}{|c|c|c|c|c|}
\hline Working & \multicolumn{3}{|c|}{ Suspicion of acute coronary syndrome } & \multirow{5}{*}{$\begin{array}{l}\text { Figure 1. Classification } \\
\text { of acute coronary syn- } \\
\text { dromes based on elec- } \\
\text { trocardiographic and } \\
\text { biochemical markers } \\
\text { (modified from [35]). } \\
\text { Abbildung 1. Eintei- } \\
\text { lung des akuten Koro- } \\
\text { narsyndroms anhand } \\
\text { der EKG-Befunde und } \\
\text { der Biomarker (modifi- } \\
\text { ziert nach [35]). }\end{array}$} \\
\hline ECG & $\begin{array}{c}\text { Persistent } \\
\text { ST elevation }\end{array}$ & $\begin{array}{l}\text { ST-T wave } \\
\text { changes }\end{array}$ & $\begin{array}{c}\text { Normal or } \\
\text { undetermined }\end{array}$ & \\
\hline & & & & \\
\hline $\begin{array}{l}\text { Biochemical } \\
\text { markers }\end{array}$ & $\begin{array}{l}\text { CK-MB or } \\
\text { troponin } \uparrow\end{array}$ & $\begin{array}{l}\text { Troponin } \\
\text { positive }\end{array}$ & $\begin{array}{c}\text { Troponin } \\
2 \times \text { negative }\end{array}$ & \\
\hline Diagnosis & STEMI & NSTEMI & $\begin{array}{c}\text { Unstable } \\
\text { angina }\end{array}$ & \\
\hline
\end{tabular}

ingly, it is recommended to initiate treatment with aspirin with an initial dose of at least 160-325 mg nonenteric aspirin followed by long-term maintenance therapy with $75-100 \mathrm{mg}$ daily. Aspirin's ability to reduce platelet aggregation is limited due to alternative pathways of platelet activation involving adenosine diphosphate (ADP), thrombin, and collagen.

Thienopyridines. The thienopyridine derivatives ticlopidine and clopidogrel irreversibly bind to the $\mathrm{P}_{12}$ ADP receptor and thereby inhibit ADP-dependent platelet activation. Ticlopidine has been largely replaced by clopidogrel due to its more favorable safety profile while preserving similar efficacy. Clopidogrel has been shown somewhat more effective than aspirin to reduce cardiovascular events ( $9 \%$ relative risk reduction) in patients with atherosclerotic disease in the CAPRIE study without increasing the risk of bleeding [11]. More importantly, dual antiplatelet therapy consisting of aspirin and clopidogrel has been shown synergistic in preventing thrombus formation and clinical 


\begin{abstract}
Figure 2. Release pattern of different cardiac biomarkers in acute myocardial infarction (obtained with permission from [47]).

Abbildung 2. Freisetzungskinetik der verschiedenen Biomarker bei akutem Myokardinfarkt (mit Genehmigung aus [47]).
\end{abstract}

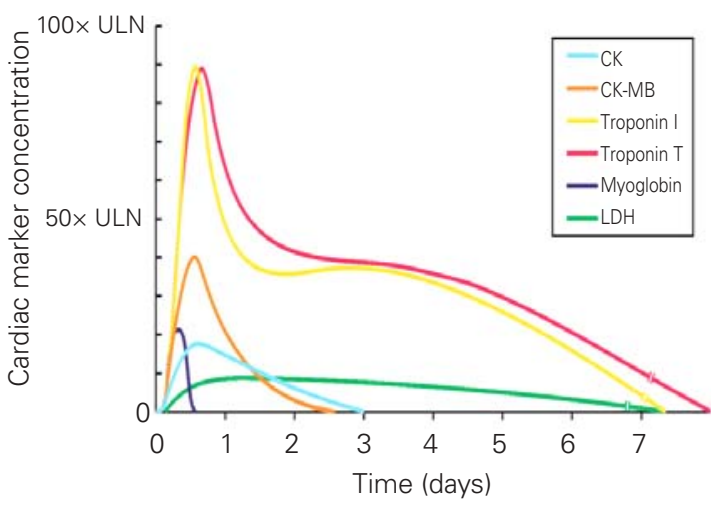

events. Thus, clopidogrel in addition to aspirin reduced the relative risk of death, nonfatal MI and stroke by $20 \%$ compared with aspirin alone in NSTE-ACS patients in the CURE trial (Figure 5) [12]. The beneficial effect of clopidogrel was present in all subgroups including those with low- and high-risk features, emerges within hours of administration and remains durable up to 1 year. In CURE, major bleeding occurred more frequently with clopidogrel and aspirin (3.7\%) than with aspirin alone $(2.7 \% ; \mathrm{p}<0.001)$, particularly in those patients undergoing coronary artery bypass grafting $(\mathrm{CABG})$, but fatal or life-threatening bleeding was similar [12]. The therapeutic benefit of dual antiplatelet therapy with clopidogrel and aspirin outweighs the in- creased risk of bleeding in patients with NSTE-ACS, but in case of CABG, clopidogrel should be discontinued 5 days before the operation to reduce the risk of bleeding.

Analyses of TARGET, PCI-CURE, and CREDO suggest that pretreatment with a loading dose of at least $300 \mathrm{mg}$ clopidogrel reduces the risk of death or $\mathrm{MI}$ in patients undergoing percutaneous coronary intervention (PCI), particularly when administered $>12 \mathrm{~h}$ before the intervention [13-15]. A loading dose of $600 \mathrm{mg}$ clopidogrel results in even more rapid and potent platelet inhibition and may be considered in patients undergoing an early invasive strategy [16]. In summary, NSTE-ACS patients should receive the following regimen:

(1) an immediate loading dose of 300-600 mg clopidogrel followed by $75 \mathrm{mg}$ clopidogrel daily in addition to aspirin. A loading dose of $600 \mathrm{mg}$ clopidogrel is preferred in patients considered for an invasive strategy undergoing PCI.

(2) The maintenance dose of $75 \mathrm{mg}$ of clopidogrel should be maintained for the duration of 1 year in the absence of an excessive bleeding risk.

(3) Clopidogrel replaces aspirin in all patients with a contraindication to aspirin.

Glycoprotein IIb/IIIa receptor inhibitors. The GP $\mathrm{IIb} / \mathrm{III}$ a receptor is an integrin found in the platelet stable angina/non-ST segment elevation myocardial infarction. *Glycoprotein Ilb/IIla inhibitors: tirofiban and eptifibatide preferred over abciximab, if started prior to coronary angiography; abciximab preferred over tirofiban and eptifibatide, if started at time of coronary intervention.

Abbildung 3. Behandlung von Patienten mit instabiler Angina pectoris/Nicht-ST-Hebungsinfarkt. ${ }^{*}$ Glykoprotein-IIb/IIla-Inhibitoren:Tirofiban und Eptifibatid werden gegenüber Abciximab bevorzugt, falls die Gabe vor der Koronarangiographie erfolgt; $\mathrm{Ab}$ ciximab wird gegenüber Tirofiban und Eptifibatid bevorzugt, falls die Gabe während der Intervention erfolgt.

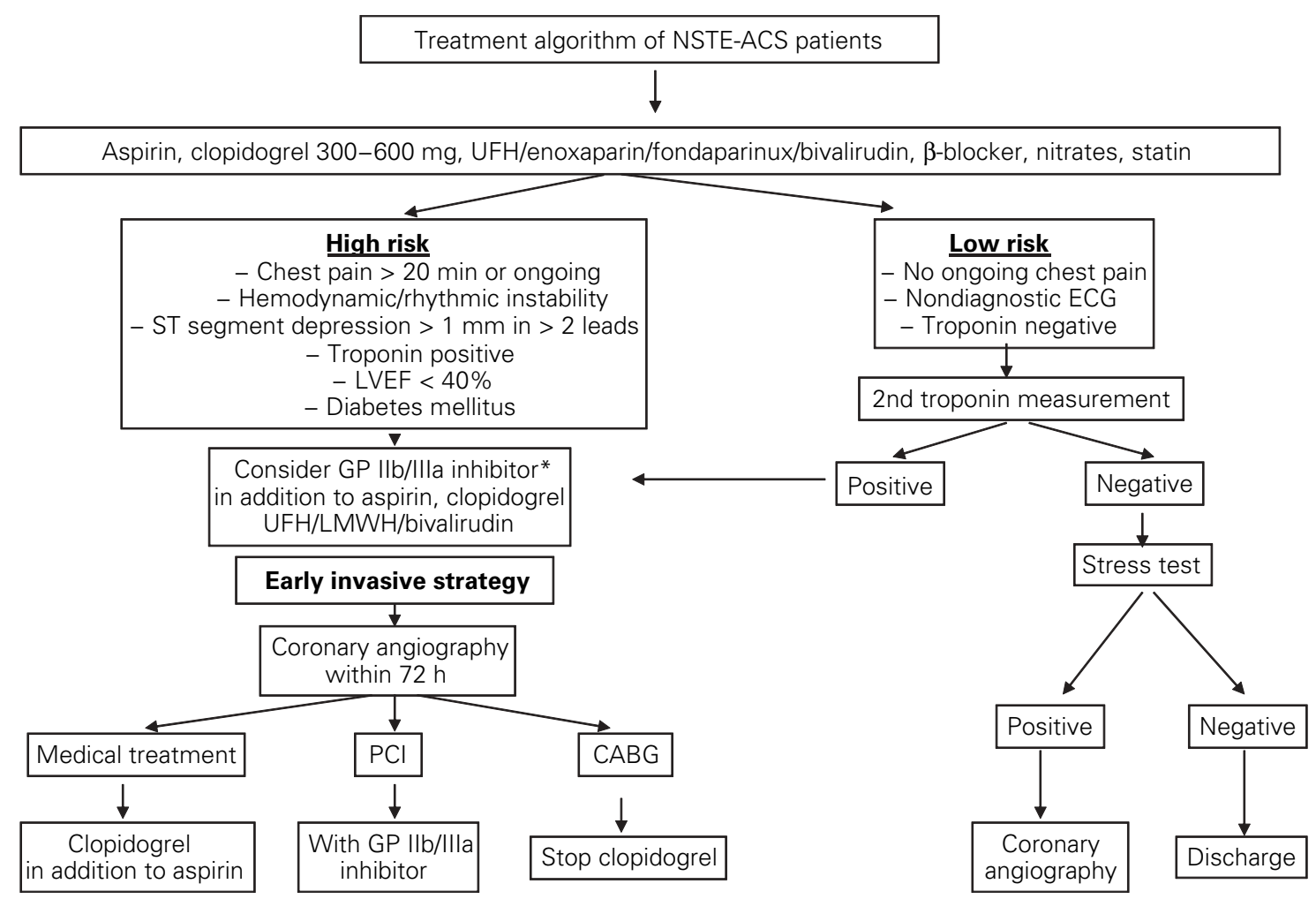


membrane and conceived as final common pathway of platelet aggregation. Platelet GP IIb/IIIa receptor inhibitors are a class of potent antiplatelet agents interfering with this receptor with currently three agents available for intravenous administration. Abciximab is a monoclonal chimeric antibody, which irreversibly binds to the GP IIb/IIIa receptor, whereas tirofiban and eptifibatide are synthetic, reversible, small-molecule inhibitors of the GP IIb/IIIa receptor. Overall, these agents have shown a modest $1 \%$ absolute and $9 \%$ relative reduction of death and nonfatal MI in NSTE-ACS patients, that was associated with a $1 \%$ increase in bleeding complications [17]. In patients with renal failure (creatinine clearance $<30 \mathrm{ml} / \mathrm{min}$ ), tirofiban requires dose adaptations, eptifibatide is contraindicated, and abciximab has no specific recommendations except for careful monitoring of bleeding complications.

NSTE-ACS patients with high-risk features, notably troponin-positive patients, those with ST segment depression, and diabetic patients $(26 \%$ relative mortality reduction), derive the greatest benefit from GP IIb/IIIa receptor inhibitors [18, 19]. Consistent results have also been obtained in NSTE-ACS patients undergoing early revascularization by PCI with a $38 \%$ relative risk reduction of death and MI (Figure 6) [17]. In addition, a meta-analysis reported a significant risk reduction in 30-day mortality among 20,186 NSTE-ACS patients undergoing PCI when GP IIb/ IIIa receptor inhibitors were used [20]. While most of the studies were performed prior to the use of thienopyridines, the benefit of abciximab in addition to clopidogrel and aspirin was recently confirmed in the ISAR-REACT 2 trial [21]. In 2,022 NSTE-ACS patients pretreated with $600 \mathrm{mg}$ clopidogrel and aspirin, abciximab reduced the 30-day risk of death, MI and urgent revascularization by $25 \%$, a benefit that was particularly pronounced in troponin-positive patients.

The two small-molecule GP IIb/IIIa receptor inhibitors tirofiban and eptifibatide may be used for "upstream" therapy, i.e., 1-2 days prior to coronary angiography and continued for $24 \mathrm{~h}$ after PCI [22-24]. By contrast, abciximab is not indicated in patients treated conservatively and should be initiated only at the time of coronary angiography when the decision to proceed with PCI has been made. In a head-to-head comparison with tirofiban in standard doses, abciximab was found superior at 30 days but not at 6 months $[15,25]$. In the recent ACUITY-TIMING trial, a deferred selective administration of GP IIb/IIIa receptor inhibitors did not meet the noninferiority criterion compared with their routine upstream use, although the increase in ischemic events was statistically not significant and limited to revascularization procedures rather than other endpoints such as death or MI [26].

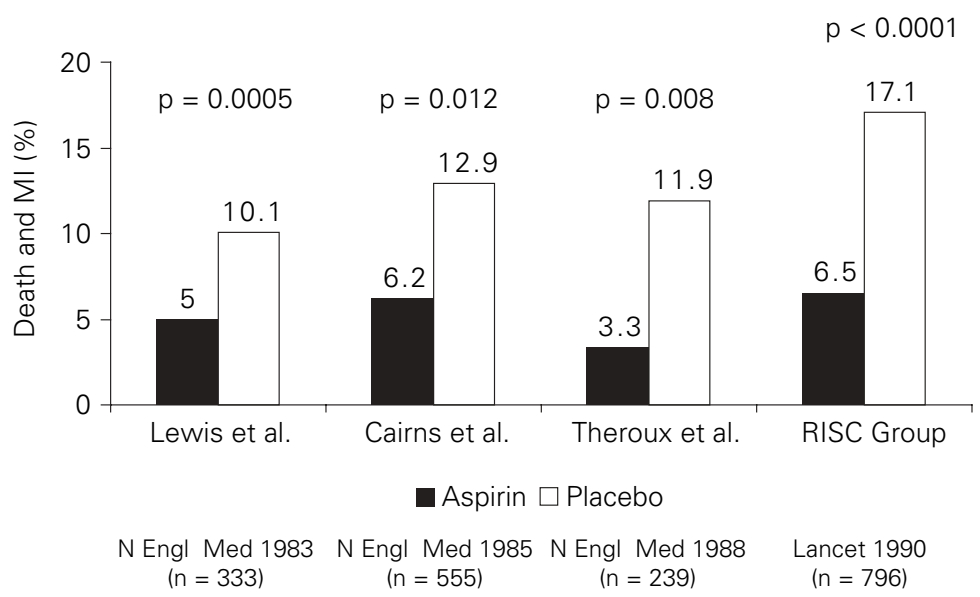

Figure 4. Beneficial effect of aspirin on incidence of death and myocardial infarction in NSTE-ACS patients in four randomized trials comparing aspirin with placebo.

Abbildung 4. Effekt von Aspirin auf Mortalität und Herzinfarkt bei Patienten mit Nicht-ST-Hebungsinfarkt in vier randomisierten Studien, welche Aspirin mit Plazebo verglichen haben.

\section{Myocardial infarction, stroke, or cardiovascular death}

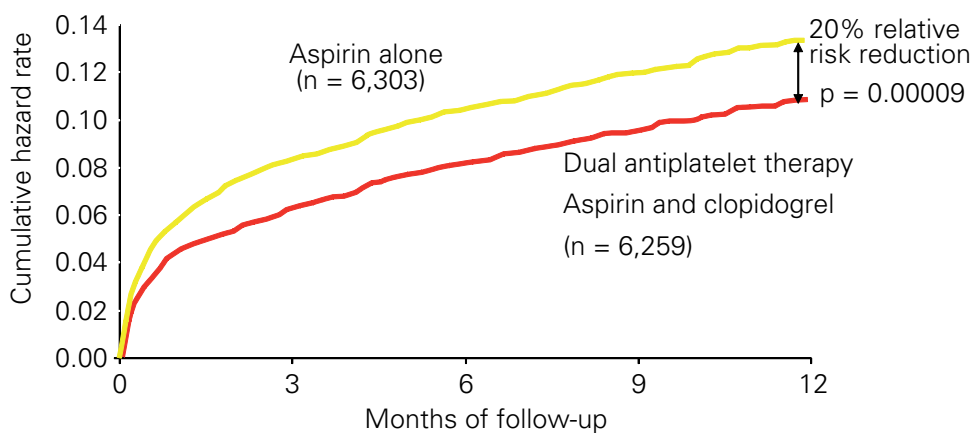

Figure 5. Effect of dual antiplatelet therapy with aspirin and clopidogrel compared with aspirin alone on the combined endpoint of death, myocardial infarction and stroke in patients with acute coronary syndromes (obtained with permission from [12]).

Abbildung 5. Einfluss der Kombinationstherapie aus Aspirin plus Clopidogrel im Vergleich zur Monotherapie mit Aspirin auf den kombinierten Endpunkt Tod, Myokardinfarkt und Hirnschlag bei Patienten mit akutem Koronarsyndrom (mit Genehmigung aus [12]).

In summary, triple antiplatelet therapy with GP $\mathrm{IIb} / \mathrm{III}$ a receptor inhibitors in addition to aspirin and clopidogrel is indicated in patients with high-risk NSTE-ACS undergoing PCI. GP IIb/IIIa receptor inhibitors must be combined with an anticoagulant. In high-risk patients not pretreated with GP IIb/IIIa receptor antagonists and undergoing PCI, abciximab is preferred over eptifibatide and tirofiban. Conversely, in patients treated upstream with GP IIb/IIIa receptor antagonists prior to angiography, eptifibatide and tirofiban are preferred over abciximab. 
Resistance to antiplatelet agents and drug-drug interactions. The questions of a clinically relevant resistance or low response to antiplatelet drugs and of drug-drug interactions of clopidogrel with statins metabolized by cytochrome $\mathrm{P} 450$ remain open for the time being. At current stage, no routine assessment of platelet aggregation inhibition can be recommended to test response to aspirin or clopidogrel. The lack of a uniform definition of "resistance" and the unknown clinical impact do not support routine testing in clinical practice. Furthermore, clopidogrel can be given in combination with any statin as there have been no conclusive clinical drug-drug interactions reported so far [27]. By contrast, there is evidence, that concomitant use of selective COX-2 inhibitors and nonselective nonsteroidal drugs in combination with aspirin or clopidogrel may be associated with an increased risk of ischemic events and, therefore, the combination of these drugs should be avoided.

\section{Anticoagulants}

Unfractionated heparin. Unfractionated heparin (UFH), a glycosaminoglycan made of polysaccharide chains ranging in molecular weight from 2,000 to 30,000 $\mathrm{Da}$, exerts its anticoagulant effect by binding to antithrombin and thus inactivates factor Xa and thrombin.

Death and myocardial infarction at 30 days

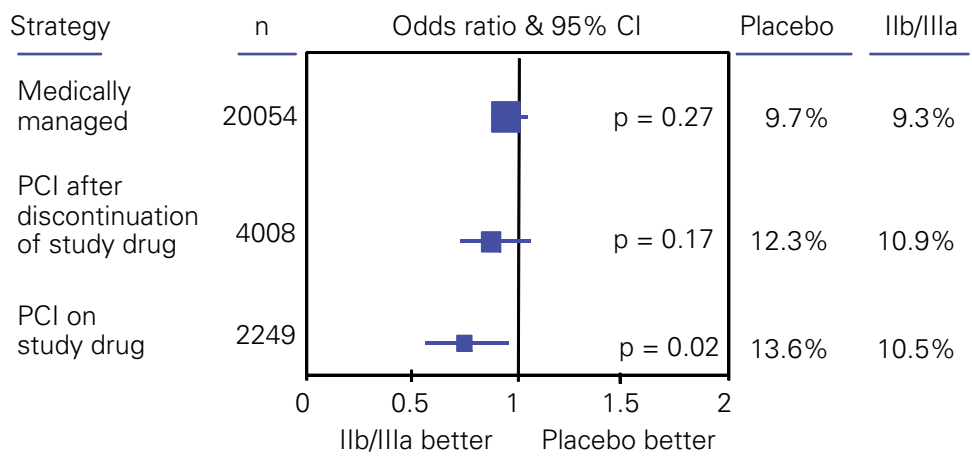

Figure 6. Differential effect of glycoprotein (GP) IIb/IIla antagonists on the combined endpoint of death and myocardial infarction in relation to revascularization therapy. Top: lack of therapeutic benefit exerted by GP IIb/IIla antagonists in patients managed conservatively. Middle: lack of therapeutic benefit exerted by GP $\mathrm{Ilb} / \mathrm{Ill}$ a antagonists in patients undergoing delayed percutaneous coronary intervention $(\mathrm{PCl})$ after discontinuation of study drug. Bottom: pronounced therapeutic benefit exerted by GP IIb/IIla antagonists in patients undergoing $\mathrm{PCI}$ during index hospitalization while on study drug. (Obtained with permission from [17].)

Abbildung 6. Effekt der Glykoprotein-(GP-)llb/Illa-Inhibitoren auf den kombinierten Endpunkt Tod und Myokardinfarkt in Abhängigkeit von der Revaskularisationstherapie. Oben: fehlender therapeutischer Nutzen der GP-IIb/IIla-Inhibitoren bei konservativ behandelten Patienten. Mitte: fehlender therapeutischer Nutzen der GP-IIb/IIla-Inhibitoren bei Patienten mit verzögerter perkutaner Koronarintervention ( $\mathrm{PCI}$ ) nach Absetzen der Studienmedikation. Unten: ausgeprägter therapeutischer Nutzen bei Gabe von GP-IIb/IIla-Inhibitoren während der PCI. (Mit Genehmigung aus [17].)
UFH is administered intravenously and has unpredictable pharmacokinetics requiring frequent anticoagulation monitoring. It should be administered as a weight-adjusted bolus of $60 \mathrm{IU} / \mathrm{kg}$ (maximal dose 4,000 IU) followed by an infusion of $12 \mathrm{IU} / \mathrm{kg} / \mathrm{h}$. Further dosing adjustments are based on measurements of activated partial thromboplastin time (aPTT, 50-70 s). If added to aspirin, UFH reduces the relative risk of death and $\mathrm{MI}$ by $33 \%$ and has been standard treatment of patients with ACS during the past 20 years [28]. UFH also exhibits prothrombogenic properties and reactivation of the coagulation process is measurable within the 1st day after UFH termination. As the anticoagulant effect of UFH is rapidly reversed by administration of protamine, due to its low cost, and the fact that it has not to be dose-adjusted in patients with renal failure, UFH is still widely used during PCI in NSTE-ACS patients.

Low-molecular-weight heparin. Low-molecularweight heparins (LMWHs) are obtained by chemical and enzymatic depolymerization of the heparin polysaccharide chains resulting in short chain fragments with a molecular weight ranging from 2,000 to 10,000 Da. LMWHs have a higher anti-Xa:anti-IIa activity than UFH, which provides for more potent inhibition of thrombin generation. Compared with UFH, the pharmacokinetic profile of LMWHs is more predictable with a high bioavailability and long plasma half-life without the need to monitor anticoagulation. In addition, LMWHs result in less platelet activation, a lower risk of heparin-induced thrombocytopenia (HIT), and can be easily administered by the subcutaneous route.

Dalteparin and nadroparin have been shown equally effective and safe as UFH in aspirin-treated NSTE-ACS patients [28]. Most evidence in NSTE-ACS patients has been generated with the LMWH enoxaparin. In the largest trial comparing UFH with enoxaparin (SYNERGY; $\mathrm{n}=10,027$ patients) with a high proportion of PCI revascularization procedures, stent implantation, and concomitant use of clopidogrel and GP IIb/ IIIa receptor antagonists, enoxaparin showed no benefit in terms of death or MI (14.0\% vs. $14.5 \%$; odds ratio $[\mathrm{OR}]=0.96,95 \%$ confidence interval $[\mathrm{CI}] 0.86-1.08)$ at 30 days, but was associated with an increased risk of TIMI major bleeding ( $9.1 \%$ vs. $7.6 \% ; p=0.008)$ [29]. A meta-analysis of all six trials comparing UFH with enoxaparin in 21,946 patients suggested a modest $9 \%$ relative risk reduction in terms of the combined endpoint of death or MI at 30 days $(10.1 \%$ vs. $11.0 \%$; OR = $0.91,95 \%$ CI $0.83-0.99)$ without a significant difference in major bleeding at 7 days $(4.7 \%$ vs. $4.5 \%$; OR $=1.04$, 95\% CI 0.89-1.10) and 30 days (Figure 7) [30]. A post-hoc subgroup analysis showed a significant reduction in death or MI in enoxaparin-treated patients, who did not receive UFH prior to randomization $(8.0 \%$ vs. $9.4 \%$; OR $=0.81,95 \%$ CI $0.70-0.94)$ without an in- 
creased risk of bleeding. Therefore, it has been suggested that the initially commenced anticoagulant (UFH or LMWH) should be continued during and after PCI to avoid crossover and combination of antithrombotic drugs, which may result in a higher risk of bleeding. Enoxaparin has also been shown safe and effective in patients undergoing PCI in conjunction with GP IIb/IIIa receptor antagonists. LMWHs should be used with caution in patients with renal insufficiency and avoided in the presence of severe renal failure (creatinine clearance $<30 \mathrm{ml} / \mathrm{min}$ ).

Direct thrombin inhibitors. Direct thrombin inhibitors (DTIs) bind directly to thrombin (factor IIa) independent of antithrombin and inhibit the conversion of fibrinogen to fibrin. In contrast to heparin, DTIs inactivate not only soluble but also fibrin-bound thrombin and therefore have an + ffect on existing thrombus. The lack of binding to plasma proteins results in a predictable anticoagulant effect, which can be monitored by measuring aPTT and ACT (activated clotting time). In addition, the half-life of DTIs is very short compared with UFH and probably responsible for the beneficial effect in terms of bleeding complications. DTIs have also an effect on platelets by reducing thrombin-induced platelet activation. Univalent DTIs comprise argatroban, melagatran and dabigatran and bind to the active site of thrombin. Bivalent DTIs such as hirudin and bivalirudin block both the active site of thrombin and exosite 1.

In a meta-analysis of eleven trials comparing various DTIs with UFH in NSTE-ACS and PCI patients, DTIs were associated with both, a reduced rate of death or MI (4.3\% vs. $5.1 \%$; OR $=0.85,95 \%$ CI $0.77-0.94 ; \mathrm{p}=0.001)$ and major bleeding $(1.9 \%$ vs. $2.3 \%$; OR $=0.75,95 \%$ CI $0.65-0.87$; $<0.001)$ [31]. While univalent DTIs showed reduced efficacy compared with UFH, hirudin was associated with a higher rate of major bleeding ( $1.7 \%$ vs. $1.3 \%$; OR $=1.28,95 \%$ CI 1.06-1.55) compared with UFH. Only bivalirudin had a favorable effect on both, efficacy (death or MI: $3.5 \%$ vs. $4.2 \%$; OR $=0.83,95 \%$ CI $0.61-1.12$ ) and safety (bleeding: $4.2 \%$ vs. $9.0 \%$; OR $=0.44,95 \% \mathrm{CI}$ 0.34-0.56) compared with UFH.

In the setting of PCI, bivalirudin was superior to UFH alone with respect to the combined endpoint of death, MI and repeat revascularization ( $6.2 \%$ vs. $7.9 \%$; $\mathrm{OR}=0.78,95 \%$ CI $0.62-0.99 ; \mathrm{p}=0.04)$, while major bleeding was significantly reduced. In the REPLACE-2 study, bivalirudin with provisional use of GP IIb/IIIa receptor antagonist was found noninferior to UFH combined with GP IIb/IIIa receptor antagonist in terms of death, MI or repeat revascularization, while major and minor bleedings were significantly reduced [32]. The ACUITY trial compared three regimens consisting of UFH/LMWH with GP IIb/IIIa receptor antago- nist, bivalirudin with GP IIb/IIIa receptor antagonist, and bivalirudin alone in 13,819 NSTE-ACS patients at moderate to high risk [48]. Three primary endpoints at 30 days were prespecified including a composite ischemia endpoint (death, MI, urgent revascularization), major bleeding, and net clinical outcome (combination of composite ischemia or major bleeding; Figures 8a to $8 \mathrm{c})$. Event rates of ischemia $(7.4 \%$ vs. $7.9 \%$; relative risk $(\mathrm{RR})=1.07,95 \% \mathrm{CI} 0.92-1.23 ; \mathrm{p}=0.39)$ and major bleeding (5.7\% vs. $5.3 \%$; RR $=0.93,95 \%$ CI $0.78-1.10$; $\mathrm{p}=0.38$ ) were similar for the two treatment arms using GP IIb/IIIa receptor antagonists regardless of UFH/ LMWH or bivalirudin use. By contrast, bivalirudin alone was found noninferior to the two treatment arms with GP IIb/IIIa receptor antagonist in terms of ischemia $(7.8 \%$ vs. $7.3 \%$; RR $=1.08,95 \%$ CI $0.93-1.24 ; p=$ 0.32 ) but significantly better with respect to major bleeding $(3.0 \%$ vs. $5.7 \%, \mathrm{RR}=0.53,95 \%$ CI $0.43-0.65$; $\mathrm{p}<0.001)$. Of note, in patients not pretreated with clopidogrel prior to PCI, the composite ischemia endpoint was more frequent in the bivalirudin alone group compared with UFH/LMWH combined with GP IIb/IIIa receptor antagonist $(9.1 \%$ vs. $7.1 \% ; \mathrm{RR}=1.29,95 \% \mathrm{CI}$ $1.03-1.63)$ with nearly significant interaction $(\mathrm{p}=0.054)$ between pretreatment with clopidogrel and the effect of bivalirudin alone, supporting the importance of adequate platelet inhibition prior to PCI. Furthermore, $41 \%$ of patients included in ACUITY were troponin-negative and therefore at lower risk, which may have led to a higher bleeding risk associated with GP $\mathrm{IIb} / \mathrm{III}$ receptor antagonists compared with bivalirudin alone without any beneficial effect on ischemia endpoints in these patients. It remains to be determined whether upstream treatment with intravenous bivalirudin prior to catheterization will find widespread use due to the relatively high cost. The infusion dose of bivalirudin should be reduced to $1.0 \mathrm{mg} / \mathrm{kg} / \mathrm{h}$ in patients with severe renal failure (creatinine clearance $<30 \mathrm{ml} / \mathrm{min}$ ) and to $0.25 \mathrm{mg} / \mathrm{kg} / \mathrm{h}$ in patients on hemodialysis.

Factor Xa inhibitors. The only factor Xa inhibitor available for clinical use is fondaparinux. It is a synthetic pentasaccharide, which inhibits factor Xa indirectly by binding to antithrombin similar to UFH and LMWH. It has no activity against thrombin. Fondaparinux is administered subcutaneously, has $100 \%$ bioavailability with an elimination half-life of $17 \mathrm{~h}$. A fixed dose of 2.5 $\mathrm{mg}$ fondaparinux once daily is recommended in NSTE-ACS patients without the need for monitoring anti-Xa activity. The drug has no measurable impact on usual anticoagulant variables including aPTT, ACT, and prothrombin time. No case of HIT has been reported in various trials and therefore monitoring of platelet counts is not necessary. Since it is eliminated mainly by the renal route, fondaparinux is contraindicated in patients with a creatinine clearance of $<30 \mathrm{ml} / \mathrm{min}$. 
Figure 7. Death, myocardial infarction, and major bleeding events at 30 days in randomized trials comparing unfractionated heparin (UFH) with low-molecular-weight heparin (LMWH) in NSTE-ACS patients (obtained with permission from [30]).

Abbildung 7. Auftreten von Tod, Myokardinfarkt und schweren Blutungen nach 30 Tagen in randomisierten Studien, die unfraktioniertes Heparin (UFH) mit niedermolekularem Heparin (LMWH) bei Patienten mit NichtST-Hebungsinfarkt verglichen haben (mit Genehmigung aus [30]).

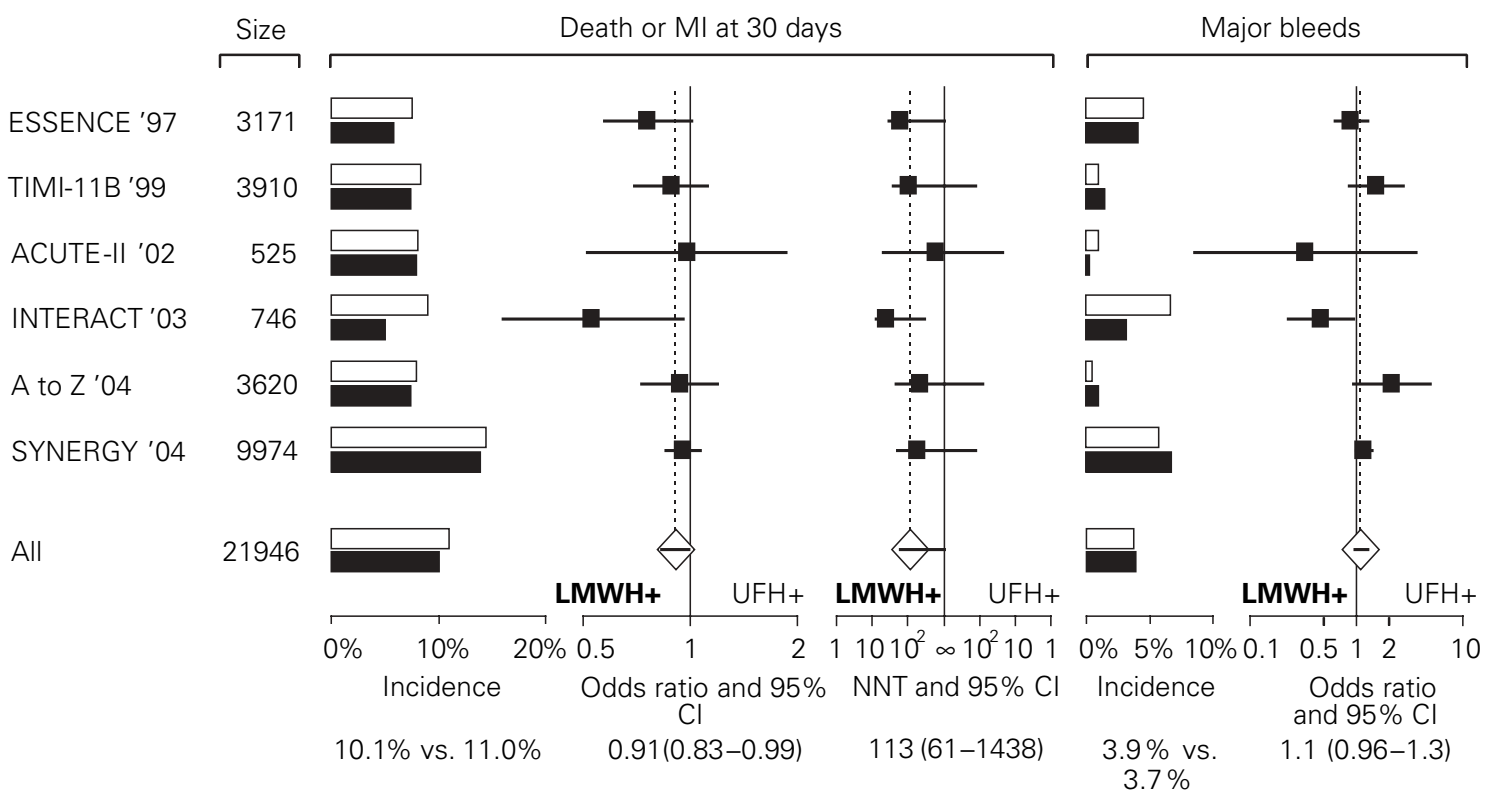

Fondaparinux $(\mathrm{n}=233)$ has been compared with UFH $(n=117)$ in the setting of PCI in a small phase II trial (ASPIRE) at doses of $2.5 \mathrm{mg}$ and $5.0 \mathrm{mg}$ and showed similar efficacy (composite of death, MI, revascularization: $6.0 \%$ vs. $6.0 \%$; hazard ratio $[\mathrm{HR}]=1.01$, 95\% CI $0.41-2.52 ; \mathrm{p}=0.97$ ) and safety (bleeding: $6.4 \%$ vs. $7.7 \%$; HR $=0.81,95 \%$ CI $0.35-1.84 ; p=0.61$ ) [33]. While catheter thrombi were reported with both UFH and fondaparinux, they were more frequent with the latter. In the OASIS-5 trial, 20,078 NSTE-ACS patients were randomly assigned to treatment with either fondaparinux $2.5 \mathrm{mg}$ s.c. once daily or enoxaparin $1 \mathrm{mg} / \mathrm{kg}$ twice daily for a mean of 6 days [34]. Fondaparinux was found noninferior to enoxaparin for the primary efficacy endpoint, a composite of death, MI, or refractory ischemia assessed at 9 days ( $5.8 \%$ vs. $5.7 \%$; HR $=1.01,95 \%$ CI $0.90-1.13)$. The rate of major bleeding at 9 days was significantly lower with fondaparinux than enoxaparin $(2.2 \%$ vs. $4.1 \%$; $\mathrm{HR}=$ $0.52,95 \%$ CI $0.44-0.61 ; \mathrm{p}<0.001)$, which resulted in a lower net clinical outcome (composite of efficacy and major bleeding in favor of fondaparinux $[7.3 \%$ vs. $9.0 \%$; $\mathrm{HR}=0.81,95 \%$ CI $0.73-0.89 ; \mathrm{p}<0.001])$. In addition, major bleeding was an independent predictor of mortality, which was significantly reduced at 30 days $(2.9 \%$ vs. $3.5 \% ; \mathrm{HR}=0.83,95 \% \mathrm{CI} 0.71-0.97 ; \mathrm{p}=0.02)$ and 6 months $(5.8 \%$ vs. $6.5 \%$; HR $=0.89,95 \%$ CI $0.80-1.00 ; \mathrm{p}$ $=0.05$; Figure 9$)$. The explanation for the higher mortality associated with bleeding remains uncertain, but has been related to rebound ischemic events due to activation of the coagulation cascade, cessation of antithrombotic therapy after a bleeding event, or adverse effects of hypotension or transfusions. Only $63 \%$ of patients in OASIS-5 had coronary angiography during hospital- ization and $34 \%$ of patients underwent revascularization by PCI. Of note, enoxaparin-treated patients received UFH during PCI, if the last dose of enoxaparin had been administered $>6 \mathrm{~h}$, a recommendation which does not correspond to current guidelines where the initial anticoagulant should be continued during PCI. Among patients undergoing PCI during hospitalization, the primary efficacy endpoint was similar for fondaparinux and enoxaparin at 9 days (9.3\% vs. $8.6 \%)$ and 30 days $(10.4 \%$ vs. $9.6 \%)$, but rates of major bleeding within $48 \mathrm{~h}$ of the procedure were lower with fondaparinux $(1.6 \%)$ than enoxaparin $(3.6 \%$; p < 0.001). However, catheter thrombosis was more frequently observed in the fondaparinux $(0.9 \%)$ than the enoxaparin $(0.3 \%)$ group. Therefore, it is recommended to administer a weight-adjusted bolus of intravenous UFH at the time of PCI in order to avoid catheter thrombosis without increasing the risk of bleeding.

In conclusion, current guidelines [35] stress the need for anticoagulation in addition to antiplatelet therapy for all NSTE-ACS patients (I-A). An individual risk assessment of ischemic as well as bleeding events should be performed, and the choice of initial treatment strategy (conservative vs. invasive) will determine which anticoagulant agent is preferred. In case of an urgent invasive strategy, UFH (I-C), enoxaparin (IIa-B), or bivalirudin (I-B) should be administered immediately. In a nonurgent situation with the decision between an early invasive and conservative strategy pending, fondaparinux has been recommended over enoxaparin (IIa-B) and UFH (IIa-B) on the basis of its more favorable safety profile (I-A). During PCI, the initial anticoagulant should be maintained in case of UFH (I-C), enoxaparin (IIa-B), and bivalirudin (I-B), where- 
No. at risk

Heparin + GP IIb/IIla inhibitor

Bivalirudin + GP $\| \mathrm{b} / \mathrm{llla}$ inhibitor

Bivalirudin alone

No. at risk

Heparin + GP IIb/IIla inhibitor

Bivalirudin + GP Ilb/llla inhibitor Bivalirudin alone

No. at risk

Heparin + GP IIb/IIla inhibitor

Bivalirudin + GP Ilb/llla inhibitor

Bivalirudin alone
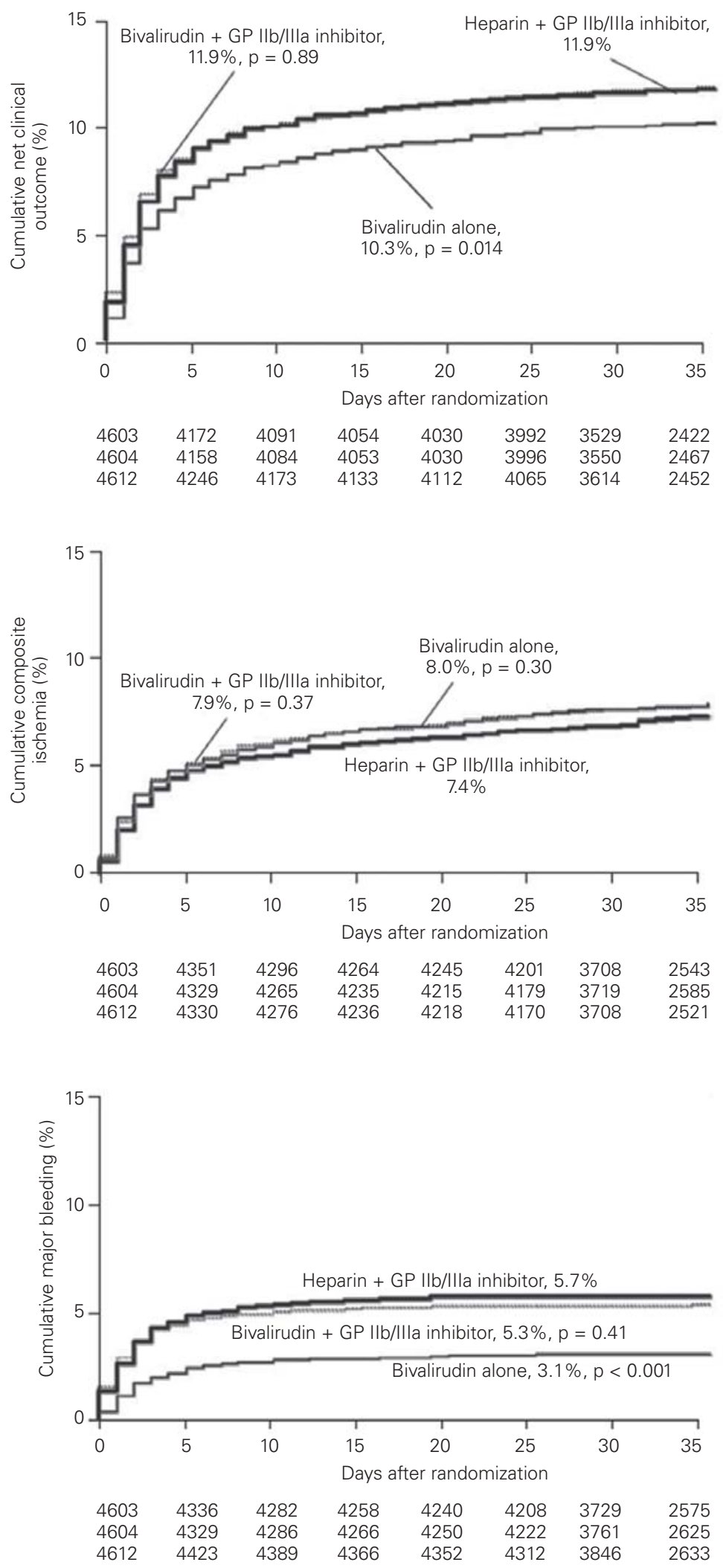

Figures $\mathbf{8 a}$ to $\mathbf{8 c}$. Kaplan-Meier event curves for the endpoints net clinical outcome (a), composite ischemia (b), and major bleeding (c) at 30 days (obtained with permission from [48]).

Abbildungen $\mathbf{8 a}$ bis $\mathbf{8 c}$. KaplanMeier-Kurven für die Endpunkte klinisches Ergebnis (a), Ischämie (b) und schwere Blutung (c) nach 30 Tagen (mit Genehmigung aus [48]). 
as a weight-adjusted bolus of intravenous UFH is necessary in case of fondaparinux (IIa-C).

\section{Anti-Ischemic Drugs}

$\boldsymbol{\beta}$-blockers. $\beta$-blockers decrease myocardial oxygen consumption, inhibit the effect of circulating catecholamines and relieve ischemic chest pain. They are recommended in all NSTE-ACS patients in the absence of contraindications. $\beta$-blockers should be used with caution in patients with heart failure, arterial hypotension, asthma, and bradyarrhythmias.

Nitrates. Nitrates cause vasodilatation of veins, arteries and arterioles by smooth muscle cell relaxation. They augment coronary collateral blood flow, reduce the frequency of coronary vasospasm, and potentially inhibit platelet aggregation. Both preload and afterload are reduced improving the ratio of oxygen demand to supply and thus reducing ischemia. As only observational data or small studies have been performed, evidence of a benefit with respect to hard clinical endpoints like death or MI is lacking. Intravenous nitrates are recommended for ongoing ischemic chest pain due to the ease of administration, titration and rapid resolution of effects as soon as the infusion is discontinued. Tolerance to nitrate therapy may develop as soon as $24 \mathrm{~h}$ after initiation of therapy and may be overcome by increasing the dose or changing the route of administration.

Calcium channel blockers. They have vasodilating effects on the coronary and peripheral circulation and may effectively relieve symptoms. A direct comparison of metoprolol with nifedipine favored the use of the $\beta$-blocker [36]. Although there are only sparse and conflicting data on the use of calcium channel blockers in NSTE-ACS patients, they are useful as treatment option in patients already receiving $\beta$-blockers and nitrates, in patients with contraindications to $\beta$-blockers and those with vasospastic angina.

\section{Coronary Revascularization in NSTE-ACS Patients}

Significant coronary artery lesions are present in $80-90 \%$ of patients with ACS. Data from the TACTICS-TIMI 18 trial revealed narrowing of the left main coronary artery in $9 \%$, single-vessel disease in $26 \%$, and three-vessel disease in $34 \%$ of patients [37]. The risk of complications during revascularization procedures is higher than in stable patients, and there has been a debate about the benefits of routine early invasive compared with a noninvasive, conservative strategy.

A meta-analysis of seven randomized clinical trials comparing routine angiography followed by revascu- larization with a conservative strategy in NSTE-ACS patients showed a reduced rate of death and MI (12.2\% vs. $14.4 \%$; OR $=0.82,95 \%$ CI $0.72-0.93 ; \mathrm{p}=0.001)$ at the end of follow-up for routine invasive versus selective invasive [38]. Similar results were found in another meta-analysis of six contemporary trials (Figure 10) [35]. However, the overall benefit came at the cost of an increased hazard during the initial hospitalization $(5.2 \%$ vs. $3.8 \%$; OR $=1.36,95 \%$ CI 1.12-1.66; $\mathrm{p}=0.002$ ), whereas the benefit emerged during the period from discharge to end of follow-up (7.4\% vs. $11.0 \%$; OR = $0.64,95 \%$ CI $0.55-0.75 ; \mathrm{p}<0.001)$. This early risk has been reduced in the setting of PCIs with the advent of clopidogrel pretreatment and GP IIb/IIIa receptor antagonists. A more recent meta-analysis of eight NSTE-ACS patient trials extended the above findings by reporting a significant $25 \%$ relative risk reduction of overall mortality at 2 years of follow-up [39]. The long-term mortality reduction has also been confirmed in the 5-year follow-up of RITA-3 [40] and FRISC-II [41]. A linear relationship between the difference in rate of revascularization between the invasive and conservative treatment arm and the derived mortality benefit has been shown in an analysis of several studies comparing a routine invasive with a selective invasive strategy. This may explain in part the lack of benefit of an early invasive strategy in the ICTUS trial, as a large proportion in the conservative arm underwent revascularization ("crossover") [42]. In addition, the majority of MIs in ICTUS (67\%; defined as more than one to three times the upper limit of normal) were procedure-related with unclear consequences on long-term prognosis.

The optimal timing of an early invasive strategy remains uncertain, since the time interval of coronary angiography varied from as short as $2.4 \mathrm{~h}$ (ISARCOOL) [43] to $96 \mathrm{~h}$ (FRISC-II) [44] and outcome results were inconsistent. Notwithstanding, it is anticipated that contemporary antiplatelet (clopidogrel, GP IIb/IIIa receptor inhibitors) and anticoagulant therapy lower the risk of periinterventional ischemic complications and therefore an invasive strategy is advised within 24 $72 \mathrm{~h}$ of admission. The greatest benefit ( $>50 \%$ relative risk reduction) of an early invasive strategy is observed in moderate- to high-risk NSTE-ACS patients, notably patients with ST segment depression and/or positive troponin test. Current practice guidelines therefore recommend an early invasive strategy consisting of coronary angiography followed by appropriate revascularization by either PCI or CABG as routine management in intermediate- to high-risk NSTE-ACS patients at facilities with adequately trained staff and appropriate equipment (I-A). In addition, an urgent invasive strategy should be entertained in patients with severe, ongoing chest pain, dynamic ST segment changes, malignant arrhythmias, and hemodynamic instability (I-C). 


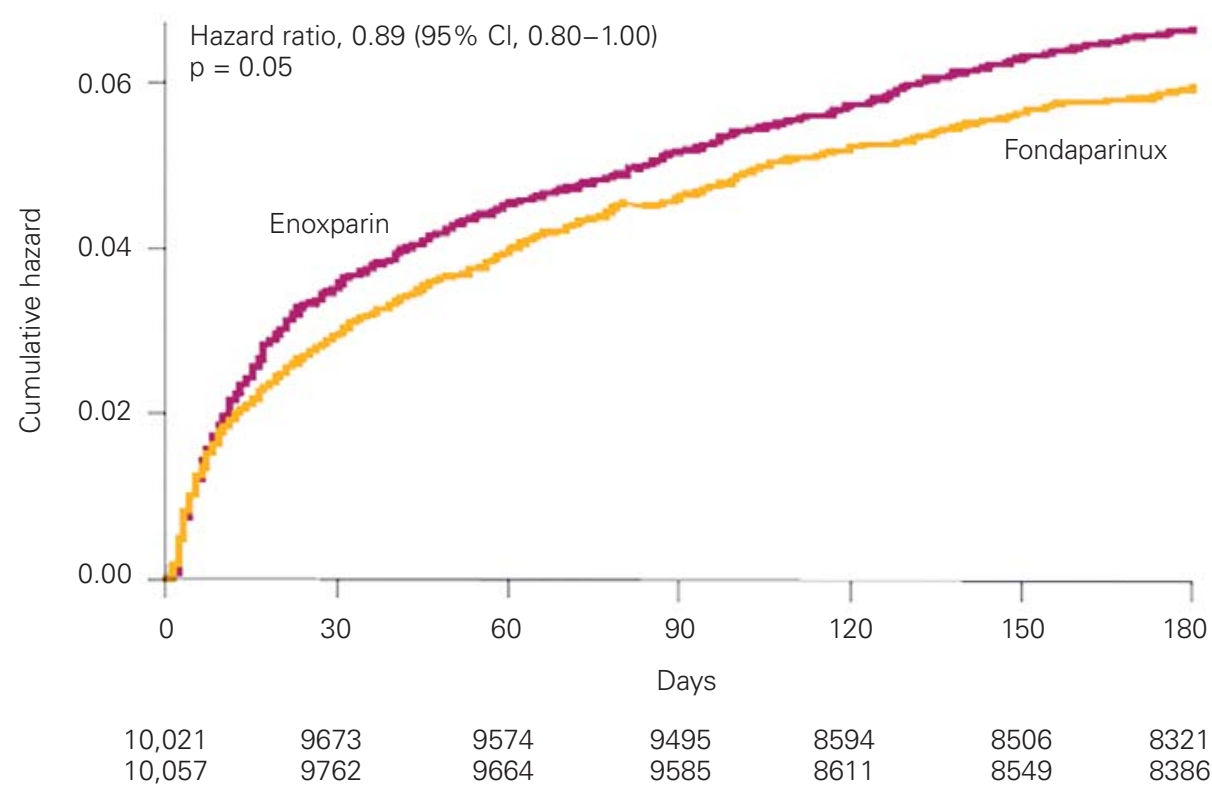

No. at risk

Enoxparin

Fondaparinux

$\begin{array}{lllllll}10,021 & 9673 & 9574 & 9495 & 8594 & 8506 & 8321 \\ 10,057 & 9762 & 9664 & 9585 & 8611 & 8549 & 8386\end{array}$

Figure 9. Cumulative risk of death at 180 days in NSTE-ACS patients randomized between enoxaparin and fondaparinux in the OASIS- 5 trial (obtained with permission from [34]).

Abbildung 9. Kumuliertes Risiko für Tod nach 180 Tagen bei Patienten mit NichtST-Hebungsinfarkt, randomisiert zwischen Enoxaparin und Fondaparinux in der OASIS-5-Studie (mit Genehmigung aus [34]).

\section{Long-Term Management}

Patients with NSTE-ACS have a similar risk of recurrent ischemic events as patients with STE-ACS. Lifestyle interventions, modification of the risk factor profile, and medical treatment are therefore crucial elements oflong-termmanagement.Lifestyleinterventions include smoking cessation, regular physical activity, and a healthy diet with low salt intake and reduced proportion of saturated fats. Current recommendations of physical exercise include 30 min of walking or jogging three to seven times per week with the goal to increase heart rate to $70 \%$ of the predicted maximum. Weight reduction is of importance in overweight patients and may be combined with physical activity. Secondary benefits from meaningful weight reduction are an improved glycemic control, a more favorable lipid profile, and better blood pressure control. The goal of weight reduction should be a body mass index of $<25 \mathrm{~kg} / \mathrm{m}^{2}$ or a waist circumference of $<88 \mathrm{~cm}$ in women and $<102$ $\mathrm{cm}$ in men. Blood pressure control aims at $<140 / 90$ $\mathrm{mmHg}$ in nondiabetic patients and $<130 / 80 \mathrm{mmHg}$ in patients with diabetes or chronic renal dysfunction. Glycemic abnormalities should be actively assessed in NSTE-ACS patients, and in patients with established diabetes, an $\mathrm{HbA}_{1 \mathrm{c}}$ level $<6.5 \%$ should be achieved.

Medical treatment with statins is a cornerstone of secondary prevention in all patients with established coronary artery disease across all subgroups regardless of baseline cholesterol levels. A meta-analysis of 13 trials in 17,963 patients attested to the safety of early statin therapy initiation and a significant reduction of ischemic events at 2 years of follow-up [45]. Current guidelines recommend combined dietary and pharmacologi- cal interventions to reduce LDL to $<100 \mathrm{mg} / \mathrm{dl}(<2.6$ $\mathrm{mmol} / \mathrm{l}$ ) initiated early (within 1-4 days) after admission. An even more aggressive reduction of LDL cholesterol among NSTE-ACS patients has been investigated in the PROVE-IT study comparing a regimen of $80 \mathrm{mg}$ atorvastatin with $40 \mathrm{mg}$ pravastatin [46]. Intensive lipid lowering resulted in a $16 \%$ relative risk reduction of death, MI, revascularization, or stroke, and the difference began to emerge after only 3 months.

$\beta$-blockers improve prognosis following NSTEACS by reducing mortality, reinfarction, and symptoms of angina and should be continued particularly in patients with reduced left ventricular function. Angiotensin-converting enzyme (ACE) inhibitors reduce mortality, reinfarction and improve ventricular remodeling following MI in patients with reduced left ventricular function. Besides their favorable effect on remodeling they may also have an antiatherogenic effect. In the absence of contraindications, ACE inhibitors should therefore be initiated early and continued long-term in all NSTE-ACS patients unless contraindicated. Their efficacy is greatest in patients at high risk, such as patients with diabetes, hypertension, chronic renal failure, signs of heart failure, and depressed left ventricular function.

As an alternative to ACE inhibitors, angiotensin II receptor blockers can be considered in case of intolerance to ACE inhibitors in patients with heart failure or reduced left ventricular function. Finally, aldosterone receptor antagonists should be considered in NSTE-ACS patients treated with ACE inhibitor and $\beta$-blocker, who have heart failure or reduced left ventricular function. A cardiac rehabilitation program is 
Figure 10. Death or myocardial infarction at 1 year in six randomized trials comparing an early invasive with a conservative strategy in NSTE-ACS patients (obtained with permission from [35]).

Abbildung 10. Tod oder Myokardinfarkt nach 1 Jahr in sechs randomisierten Studien, die eine frühe invasive Strategie mit einer konservativen Therapie bei Patienten mit Nicht-ST-Hebungsinfarkt verglichen haben (mit Genehmigung aus [35]).

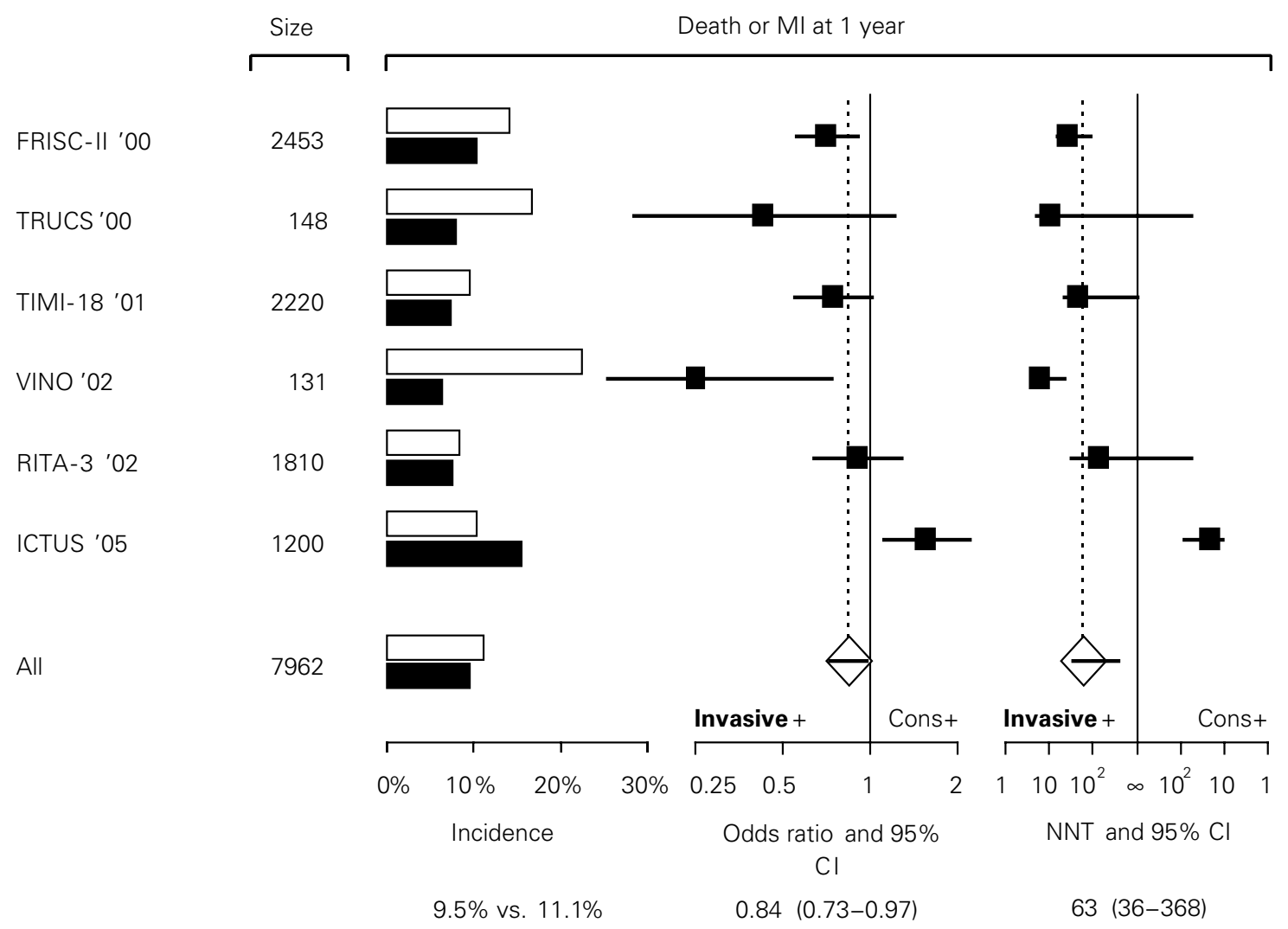

recommended to achieve the goals of secondary prevention. An exercise stress test to assess functional capacity is advised within 4-7 weeks after admission for NSTE-ACS [35].

Conflict of interest: None. The authors declare that they have no financial or personal relations to other parties whose interests could have affected the content of this article in any way, either positively or negatively.

\section{References}

1. Ross R. Atherosclerosis - an inflammatory disease. N Engl J Med 1999;340:115-26.

2. Hamm CW, Bertrand M, Braunwald E. Acute coronary syndrome without ST elevation: implementation of new guidelines. Lancet 2001;358:1533-8.

3. Savonitto S, Ardissino D, Granger CB, et al. Prognostic value of the admission electrocardiogram in acute coronary syndromes. JAMA 1999;281:707-13.

4. Antman EM, Tanasijevic MJ, Thompson B, et al. Cardiac-specific troponin I levels to predict the risk of mortality in patients with acute coronary syndromes. N Engl J Med 1996;335:1342-9.

5. Granger CB, Goldberg RJ, Dabbous O, et al. Predictors of hospital mortality in the global registry of acute coronary events. Arch Intern Med 2003;163:2345-53.

6. Antman EM, Cohen M, Bernink PJ, et al. The TIMI risk score for unstable angina/non-ST elevation MI: a method for prog- nostication and therapeutic decision making. JAMA 2000;284:835-42.

7. Cairns JA, Gent $M$, Singer J, et al. Aspirin, sulfinpyrazone, or both in unstable angina. Results of a Canadian multicenter trial. N Engl J Med 1985;313:1369-75.

8. Theroux P, Ouimet H,McCans J, et al. Aspirin, heparin, or both to treat acute unstable angina. N Engl J Med 1988;319: 1105-11.

9. Risk of myocardial infarction and death during treatment with low dose aspirin and intravenous heparin in men with unstable coronary artery disease. The RISC Group. Lancet 1990;336:827-30.

10. Peters RJ, Mehta SR, Fox KA, et al. Effects of aspirin dose when used alone or in combination with clopidogrel in patients with acute coronary syndromes: observations from the Clopidogrel in Unstable angina to prevent Recurrent Events (CURE) study. Circulation 2003;108:1682-7.

11. A randomised, blinded, trial of clopidogrel versus aspirin in patients at risk of ischaemic events (CAPRIE). CAPRIE Steering Committee. Lancet 1996;348:1329-39.

12. Yusuf S, Zhao F, Mehta SR, et al. Effects of clopidogrel in addition to aspirin in patients with acute coronary syndromes without ST-segment elevation. N Engl J Med 2001; 345:494-502.

13. Mehta SR, Yusuf S, Peters RJ, et al. Effects of pretreatment with clopidogrel and aspirin followed by long-term therapy in patients undergoing percutaneous coronary intervention: the PCI-CURE study. Lancet 2001;358:527-33.

14. Steinhubl SR, Berger PB, Mann JT 3rd, et al. Early and sustained dual oral antiplatelet therapy following percutaneous coronary intervention: a randomized controlled trial. JAMA 2002;288:2411-20.

15. Topol EJ, Moliterno DJ, Herrmann HC, et al. Comparison of two platelet glycoprotein Ilb/IIla inhibitors, tirofiban and abciximab, for the prevention of ischemic events with 
percutaneous coronary revascularization. N Engl J Med 2001;344:1888-94.

15. Beckerath N von, Taubert D, Pogatsa-Murray G, et al. Absorption, metabolization, and antiplatelet effects of 300-, 600-, and 900-mg loading doses of clopidogrel: results of the ISAR-CHOICE (Intracoronary Stenting and Antithrombotic Regimen: Choose Between 3 High Oral Doses for Immediate Clopidogrel Effect) trial. Circulation 2005;112:2946-50.

17. Roffi M, Chew DP, Mukherjee D, et al. Platelet glycoprotein Ilb/IIla inhibition in acute coronary syndromes. Gradient of benefit related to the revascularization strategy. Eur Heart J 2002;23:1441-8.

18. Boersma E, Harrington RA, Moliterno DJ, et al. Platelet glycoprotein Ilb/IIla inhibitors in acute coronary syndromes. Lancet 2002;360:342-3

19. Roffi M, Chew DP, Mukherjee D, et al. Platelet glycoprotein Ilb/IIla inhibitors reduce mortality in diabetic patients with non-ST-segment-elevation acute coronary syndromes. Circulation 2001;104:2767-71.

20. Kong DF, Hasselblad V, Harrington RA, et al. Meta-analysis of survival with platelet glycoprotein Ilb/IIla antagonists for percutaneous coronary interventions. Am J Cardiol 2003;92:651-5.

21. Kastrati A, Mehilli J, Neumann FJ, et al. Abciximab in patients with acute coronary syndromes undergoing percutaneous coronary intervention after clopidogrel pretreatment: the ISAR-REACT 2 randomized trial. JAMA 2006;295: 1531-8.

22. Effects of platelet glycoprotein Ilb/IIla blockade with tirofiban on adverse cardiac events in patients with unstable angina or acute myocardial infarction undergoing coronary angioplasty. The RESTORE Investigators. Randomized Efficacy Study of Tirofiban for Outcomes and REstenosis. Circulation 1997;96:1445-53.

23. Inhibition of platelet glycoprotein IIb/IIla with eptifibatide in patients with acute coronary syndromes. The PURSUIT Trial Investigators. Platelet Glycoprotein Ilb/IIla in Unstable Angina: Receptor Suppression Using Integrilin Therapy. N Engl J Med 1998;339:436-43.

24. ESPRIT Investigators. Novel dosing regimen of eptifibatide in planned coronary stent implantation (ESPRIT): a randomised placebo-controlled trial. Lancet 2000;356:2037-44.

25. Moliterno DJ, Yakubov SJ, DiBattiste PM, et al. Outcomes at 6 months for the direct comparison of tirofiban and abciximab during percutaneous coronary revascularisation with stent placement: the TARGET follow-up study. Lancet 2002;360:355-60.

26 Stone GW, White HD, Ohman EM, et al. Bivalirudin in patients with acute coronary syndromes undergoing percutaneous coronary intervention: a subgroup analysis from the Acute Catheterization and Urgent Intervention Triage Strategy (ACUITY) trial. Lancet 2007:369:907-19.

27. Saw J, Brennan DM, Steinhubl SR, et al. Lack of evidence of a clopidogrel-statin interaction in the CHARISMA trial. J Am Coll Cardiol 2007:50:291-5.

28. Eikelboom JW, Anand SS, Malmberg K, et al. Unfractionated heparin and low-molecular-weight heparin in acute coronary syndrome without ST elevation: a meta-analysis. Lancet 2000;355:1936-42.

29. Ferguson JJ, Califf RM, Antman EM, et al. Enoxaparin vs unfractionated heparin in high-risk patients with non-ST-segment elevation acute coronary syndromes managed with an intended early invasive strategy: primary results of the SYNERGY randomized trial. JAMA 2004;292:45-54.

30. Petersen JL, Mahaffey KW, Hasselblad V, et al. Efficacy and bleeding complications among patients randomized to enoxaparin or unfractionated heparin for antithrombin therapy in non-ST-segment elevation acute coronary syndromes: a systematic overview. JAMA 2004;292:89-96.

31. Direct thrombin inhibitors in acute coronary syndromes: principal results of a meta-analysis based on individual patients' data. Lancet 2002;359:294-302.

32. Lincoff AM, Bittl JA, Harrington RA, et al. Bivalirudin and provisional glycoprotein Ilb/IIla blockade compared with hepa- rin and planned glycoprotein IIb/IIla blockade during percutaneous coronary intervention: REPLACE-2 randomized trial. JAMA 2003;289:853-63.

33. Mehta SR, Steg PG, Granger CB, et al. Randomized, blinded trial comparing fondaparinux with unfractionated heparin in patients undergoing contemporary percutaneous coronary intervention: Arixtra Study in Percutaneous coronary Intervention: a Randomized Evaluation (ASPIRE) pilot trial. Circulation 2005;111:1390-7.

34. The Fifth Organization to Assess Strategies in Acute Ischemic Syndromes Investigators. Comparison of fondaparinux and enoxaparin in acute coronary syndromes. N Engl J Med 2006;354:1464-76.

35. Bassand JP, Hamm CW, Ardissino D, et al. Guidelines for the diagnosis and treatment of non-ST-segment elevation acute coronary syndromes. The Task Force for the Diagnosis and Treatment of Non-ST-Segment Elevation Acute Coronary Syndromes of the European Society of Cardiology. Eur Heart 2007; 28:1598-66o.

36. Lubsen J, Tijssen JG. Efficacy of nifedipine and metoprolol in the early treatment of unstable angina in the coronary care unit: findings from the Holland Interuniversity Nifedipine/ metoprolol Trial (HINT). Am J Cardiol 1987;60: 18A-25A

37. Cannon CP, Weintraub WS, Demopoulos L, et al. Results of the Treat Angina with Aggrastat and Determine Cost of Therapy with an Invasive or Conservative Strategy (TACTICS-TIMI 18) trial. Circulation 2000;102:2672.

38. Bavry AA, Kumbhani DJ, Rassi AN, et al. Benefit of early invasive therapy in acute coronary syndromes: a meta-analysis of contemporary randomized clinical trials. J Am Coll Cardiol 2006;48:1319-25.

39. Hoenig MR, Doust JA, Aroney CN, et al. Early invasive versus conservative strategies for unstable angina \& non-ST-elevation myocardial infarction in the stent era. Cochrane Database Syst Rev 2006;3:CDoo4815

40. Fox KA, Poole-Wilson P, Clayton TC, et al. 5-year outcome of an interventional strategy in non-ST-elevation acute coronary syndrome: the British Heart Foundation RITA-3 randomised trial. Lancet 2005;366:914-20.

41. Lagerqvist B, Husted S, Kontny F, et al. 5-year outcomes in the FRISC-II randomised trial of an invasive versus a non-invasive strategy in non-ST-elevation acute coronary syndrome: a follow-up study. Lancet 2006;368:998-1004.

42. Hirsch A, Windhausen F, Tijssen JG, et al. Long-term outcome after an early invasive versus selective invasive treatment strategy in patients with non-ST-elevation acute coronary syndrome and elevated cardiac troponin T (the ICTUS trial): a follow-up study. Lancet 2007;369:827-35.

43. Neumann FJ, Kastrati A, Pogatsa-Murray G, et al. Evaluation of prolonged antithrombotic pretreatment ("cooling-off" strategy) before intervention in patients with unstable coronary syndromes: a randomized controlled trial. JAMA 2003;290:1593-9.

44. Wallentin L, Lagerqvist B, Husted S, et al. Outcome at 1 year after an invasive compared with a non-invasive strategy in unstable coronary-artery disease: the FRISC II invasive randomised trial. FRISC II Investigators. Fast Revascularisation during Instability in Coronary artery disease. Lancet 2000 356:9-16.

45. Hulten E, Jackson JL, Douglas K, et al. The effect of early, in tensive statin therapy on acute coronary syndrome: a meta-analysis of randomized controlled trials. Arch Intern Med 2006;166:1814-21.

46. Ridker PM, Cannon CP, Morrow D, et al. C-reactive protein levels and outcomes after statin therapy. N Engl J Med 2005;352:20-8.

47. Windecker S. Acute coronary syndromes. In: Albert RK Slutsky A, Ranieri M, et al., eds. Clinical critical care medicine. Philadelphia: Mosby Elsevier,2006.

48. Stone G, McLaurin BT, Cox DA, et al. Bivalirudin for patients with acute coronary syndromes. N Engl J Med 2006;355: 2203-16.

\section{Address for Correspondence}

Professor Stephan Windecker, MD

Director Invasive

Cardiology

Department of Cardiology University Hospital Bern 3010 Bern Switzerland Phone (41/31) 632-4497,

Fax -4770 e-mail: stephan windecker@insel.ch 